\title{
STATUS BIOTA PENEMPEL PASCA PENANAMAN MANGROVE Rhizophora spp. DI KEPULAUAN SERIBU: STUDI KASUS FILUM MOLUSKA
}

\author{
Syahrial $^{a}$, Dandi Saleky ${ }^{\mathrm{b}}$, Rosa Delima Pangaribuan ${ }^{\mathrm{b}}$, Simon P. O. Leatemia $^{\mathrm{c}}$, Nur Rahma Putri ${ }^{\mathrm{d}}$ \\ ${ }^{a}$ Wahana Alam Bahari. Jl. Syech Umar Pangkalan Sesai Dumai Barat, Kota Dumai 28824 \\ bJurusan Manajemen Sumberdaya Perairan Univ. Musamus Jl. Kamizaun Mopah Lama, Merauke 99600 \\ `Jurusan Manajemen Sumberdaya Perairan Univ. Papua Jl. Gunung Salju Amban, Manokwari 98314 \\ ${ }^{\mathrm{d}}$ Belukap Mangrove Club \\ Jl. HR. Soebrantas Km 12,5 Simpang Baru Tampan, Pekanbaru 28293 \\ *Koresponden penulis : syahrial.bmc@gmail.com
}

\begin{abstract}
Abstrak
Reboisasi mangrove telah banyak dilakukan di berbagai wilayah. Hal ini bermaksud untuk mempertahankan kelestarian mangrove agar tetap menjaga keseimbangan iklim global, melindungi pantai, bermanfaat bagi nelayan, tempat tumbuh, mencari makan dan berkembang biak bagi biota laut maupun pesisir. Kajian status biota penempel di kawasan reboisasi mangrove Rhizophora spp. Kepulauan Seribu telah dilakukan pada bulan Maret 2014. Hal ini bertujuan untuk memonitoring hasil dari kegiatan rehabilitasi mangrove Kepulauan Seribu dengan spesies tanam Rhizophora spp. terhadap komunitas biota penempel khususnya filum moluska. Data biota penempel di kawasan reboisasi mangrove Kepulauan seribu dikumpulkan dengan membuat transek garis dan plot yang ditarik dari titik acuan (tegakan mangrove terluar) dan tegak lurus garis pantai sampai ke daratan. Kemudian transek garis dibuat petak-petak contoh (plot) dengan ukuran 10 x $10 \mathrm{~m}$ dan di dalam ukuran $10 \times 10$ m tersebut dibuat plot kecil (sub plot) yang berukuran 1 x $1 \mathrm{~m}$, sedangkan pengukuran kualitas perairan dilakukan secara in-situ. Hasil penelitian memperlihatkan bahwa biota penempel dari filum moluska ditemukan sebanyak 3 spesies gastropoda dan 1 spesies bivalvia, dimana gastropoda Littoraria scabra merupakan komposisi yang paling tinggi (92.23\%) dengan kepadatan biota tertingginya berada di Stasiun 2 maupun 3 (masing-masing 04.00 ind $/ \mathrm{m}^{2}$ ). Indeks keanekaragaman ketiga stasiunnya tergolong rendah, sehingga menyebabkan dominansinya tergolong tinggi dan keseragamannya mengalami tekanan. Selain itu, pola penyebaran biota penempel di kawasan reboisasi mangrove Rhizophora spp. Kepulauan Seribu tergolong seragam dan berkelompok, dimana karakteristik lingkungan tidak sebagai faktor pembatas bagi kelangsungan hidup mangrove maupun biota penempelnya.
\end{abstract}

Kata Kunci: Biota Penempel, Gastropoda, Bivalvia, Reboisasi, Mangrove, Kepulauan Seribu

\begin{abstract}
Mangrove reforestation has been carried out in various regions. This is intended to maintain the sustainability of mangroves in order to maintain a global climate balance, protect the coast, benefit fishermen, grow places, look for food and breed for marine and coastal biota. Study of the status of attaching biota in the Rhizophora spp. mangrove reforestation area. The Thousand Islands was carried out in March 2014. This was aimed at monitoring the results of the rehabilitation activities of the Thousand Islands mangrove with planting species Rhizophora spp. towards the community of attaching biota, especially mollusk phylum. Data on attachment biota in the Thousand Islands mangrove reforestation area were collected by making line transects and plots drawn from the reference point (outermost mangrove stands) and perpendicular to the coastline to the mainland. Then line transects are made of plots of size $10 \times 10 \mathrm{~m}$ and in a size of $10 \times 10 \mathrm{~m}$, a small plot (subplot) measuring $1 \times 1 \mathrm{~m}$ is made, while measurements of water quality are carried out in-situ. The results showed that the attachment biota of the molluscum phylum were found in 3 gastropod species and 1 species of bivalves, where Littoraria scabra gastropods was the highest composition (92.23\%) with the highest density of biota at Station 2 and 3 (04.00 ind// $\mathrm{m}^{2}$ respectively). The diversity index of the three stations is relatively low, causing high dominance and uniformity. In addition, the distribution patterns of attaching biota in the Rhizophora spp. mangrove reforestation area. The Thousand Islands are classified as uniform and in groups, where environmental characteristics are not a limiting factor for the survival of mangroves and their attaching biota.
\end{abstract}

Keywords: Adhere Biota, Gastropods, Bivalvia, Reforestation, Mangroves, Seribu Islands 


\section{PENDAHULUAN}

Hutan mangrove merupakan ekosistem lahan basah yang sensitif terhadap pasang surut dan terletak di sepanjang pantai tropis maupun subtropis $[1 ; 2]$, berada diantara $30^{\circ}$ Lintang Utara dan Selatan [3; 4], banyak terkonsentrasi di daerah tropis daripada subtropis $\left(181000 \mathrm{~km}^{2}\right)$ [5], meliputi 15 juta ha $[6 ; 7]$ dengan area cakupan sekitar $1.7 \times$ $105 \mathrm{~km}^{2}$ [8] dan tersebar di 121 negara [6;7]. Menurut [9] hutan mangrove global telah mengalami penurunan dan mungkin lebih cepat penurunannya daripada jenis hutan tropis lainnya. Sekitar $20-35 \%$ kawasan mangrove global telah hilang sejak tahun 1980 - 2000 [10; 11; 12; 13; 14]. Di Delta Mangoky (Madagaskar) misalnya, mangrovenya mengalami deforestasi yang sangat tinggi pada tahun 1980 - 1990 [11], kemudian di Teluk Tampa (Florida), 40\% hutan mangrovenya telah hilang atau rusak dari tahun 1960 - 1965 [15]. Selanjutnya di sepanjang garis pantai Pulau Lamu (Kenya), mengalami kerusakan sekitar $85 \%$ dari tahun 1941 - 1956 [16], kemudian dari tahun 2000 - 2012, hutan mangrove di Grenada telah mengalami kerusakan sekitar $0.29 \%$, Taiwan $0.30 \%$, Ghana $0.31 \%$, Kamboja $0.37 \%$, Malaysia $0.41 \%$, Curacao $0.48 \%$, Guatemala $0.53 \%$, Aruba $0.64 \%$, Myanmar $0.70 \%$ serta Saint Kitts dan Nevis $1.67 \%$ [17].

[18] menyatakan bahwa apabila semakin rusak ekosistem mangrove, maka akan semakin diperlukan usaha untuk pemulihannya. Dalam arti lain reboisasi mangrove menjadi kegiatan yang utama di seluruh dunia $[19 ; 20 ; 21]$ seperti yang dilakukan di kawasan Indian River Lagoon Florida seluas 12000 ha [22], Pulau Bohol Filipina 100 ha [23] maupun di Malaysia 1819 ha [24]. Sementara di Indonesia sendiri, telah dilakukan di pesisir Provinsi Sumatera Utara seluas 701.83 ha [25], Pantai Utara Jawa 20000 ha [26], Riau 256 ha [27] dan Cilacap 105 ha [27], sedangkan di Kepulauan Seribu masih belum terdata.

Terlepas dari hal di atas, [28] menyatakan bahwa Rhizophora merupakan kelompok tumbuhan yang sering digunakan untuk kegiatan rehabilitasi mangrove di Indonesia, kemudian [29] menyatakan bahwa fauna (epi- atau infauna) dapat digunakan sebagai bioindikator pemulihan saat reboisasi mangrove. Pernyataan yang sama juga dinyatakan oleh [30] dan [31]. Mengingat sering diabaikannya komunitas fauna dalam kegiatan pengelolaan mangrove yang telah direhabilitasi [32] dan kajian tentang makrofauna sebagai pengukur hasil kegiatan reboisasi mangrove juga masih sedikit [33], maka kajian status biota penempel di kawasan reboisasi mangrove Rhizophora spp. Kepulauan Seribu sangat perlu dilakukan. Hal ini bertujuan untuk memonitoring hasil kegiatan rehabilitasi mangrove di Kepulauan Seribu (spesies tanam Rhizophora spp.) terhadap komunitas biota penempel khususnya filum moluska.

\section{METODE}

\section{Waktu dan Tempat Penelitian}

Penelitian dilaksanakan pada bulan April 2014 di kawasan reboisasi mangrove Kabupaten Kepulauan Seribu Provinsi Daerah Khusus Ibukota (DKI) Jakarta. Stasiun 1 berada di Pulau Pramuka, Stasiun 2 di Pulau Panggang dan Stasiun 3 di Pulau Karya (Gambar 1). Stasiun 1 merupakan lokasi penanaman yang berdekatan dengan permukiman penduduk, sedangkan Stasiun 2 dan 3 merupakan lokasi penanaman yang berdekatan dengan ekosistem padang lamun.

\section{Alat dan Bahan Penelitian}

Alat yang digunakan dalam penelitian ini adalah rol meter, buku identifikasi siput dan kerang [34], data sheet, kamera, GPS Garmin 62 series, alat tulis, kantong plastik polyethylene, water quality meter (suhu, salinitas, pH) dan cool box. Sementara bahan yang digunakan adalah alkohol $70 \%$ untuk pengawetan biota penempel mangrove dan aquades untuk mengkalibrasi alat kualitas air. 


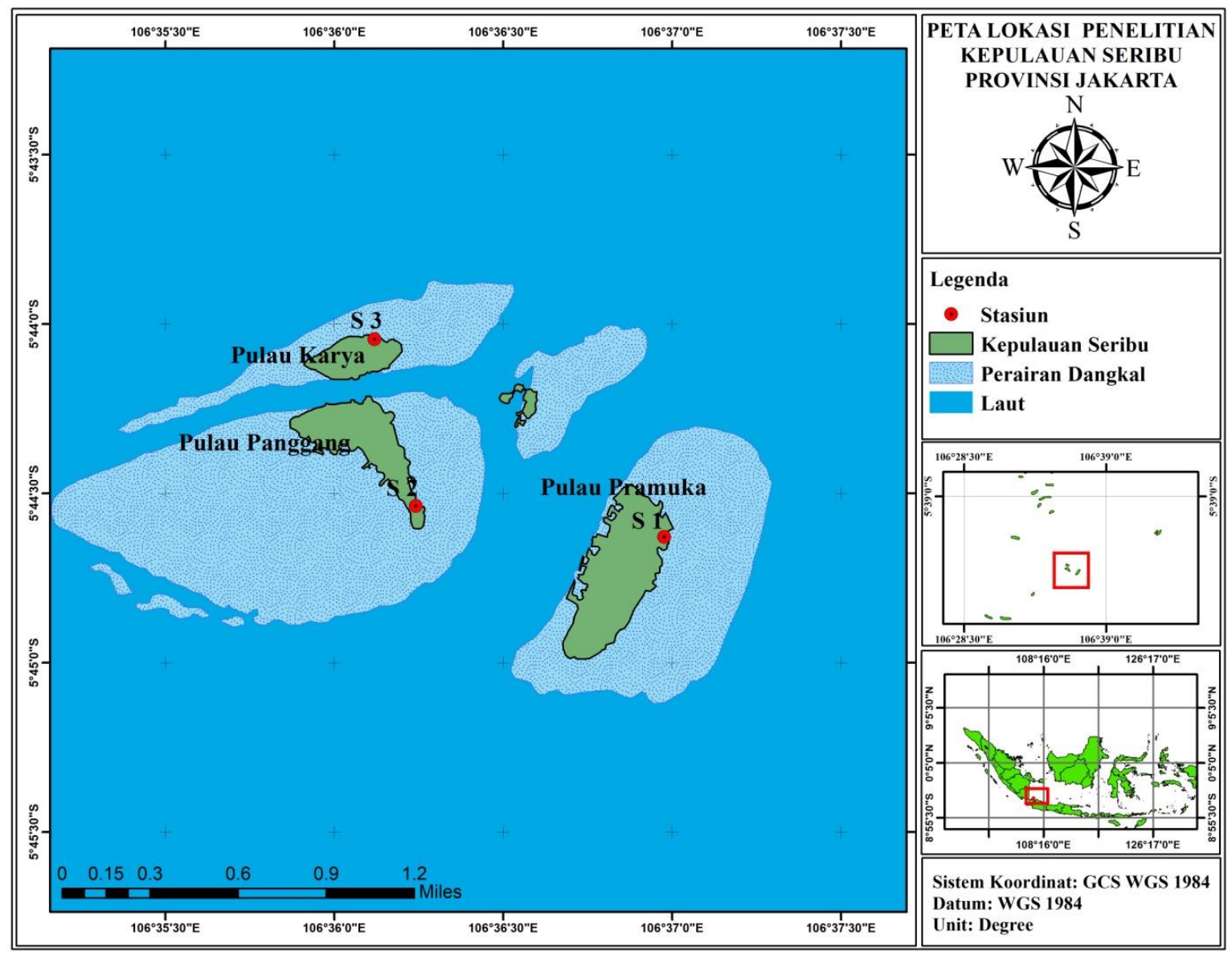

Gambar.1 Peta lokasi penelitian

\section{Pengumpulan Data Kualitas Perairan}

Pengukuran kualitas perairan dilakukan dengan cara in-situ yaitu mengambil contoh air pada masing-masing stasiun pengamatan. Parameter kualitas perairan yang diukur meliputi suhu perairan, $\mathrm{pH}$ dan salinitas dengan menggunakan water quality meter AZ-8603. Sementara parameter oksigen terlarut (DO) menggunakan data sekunder yang diambil pada waktu yang hampir bersamaan dan berdekatan dengan kajian ini.

\section{Pengumpulan Data Biota Penempel Mangrove}

Data biota penempel di kawasan reboisasi mangrove Kepulauan seribu dikumpulkan dengan membuat transek garis dan plot yang ditarik dari titik acuan (tegakan mangrove terluar) dan tegak lurus garis pantai sampai ke daratan, kemudian transek garis dibuat petak-petak contoh (plot) dengan ukuran 10 x $10 \mathrm{~m}$ dan di dalam ukuran $10 \mathrm{x}$
$10 \mathrm{~m}$ tersebut dibuat plot kecil (sub plot) yang berukuran $1 \mathrm{x} 1 \mathrm{~m}$ sebanyak 5 plot [35].

\section{Analisis Kepadatan Biota Penempel Mangrove}

Untuk analisis kepadatan biota penempel di kawasan reboisasi mangrove Kepulauan Seribu mengacu pada $[36 ; 37 ; 38$; 39].

\section{Analisis Keanekaragaman, Dominansi dan Keseragaman Biota Penempel Mangrove}

Analisis keanekaragaman biota penempel di kawasan reboisasi mangrove Kepulauan Seribu dianalisis menggunakan Indeks keanekaragaman Shannon-Weaver dengan kriteria $\mathrm{H}^{\prime} \leq 2.0$ (keanekaragaman rendah), $2.0<\mathrm{H}^{\prime} \leq 3.0$ (keanekaragaman sedang) dan $\mathrm{H}^{\prime} \geq 3.0$ (keanekaragaman tinggi) [40], sedangkan untuk analisis dominansinya menggunakan Indeks dominansi Simpson dengan kriteria $0<\mathrm{C} \leq$ 0.5 (dominansi rendah), $0.5<\mathrm{C} \leq 0.75$ 
(dominansi sedang) dan $0.75<\mathrm{C} \leq 1$ (dominansi tinggi) [40]. Selanjutnya untuk analisis keseragaman biota penempel di kawasan reboisasi mangrove Kepulauan Seribu, dianalisis menggunakan Indeks keseragaman Shannon-Weaver dengan kriteria $0<\mathrm{E} \leq 0.5$ (komunitas dalam keadaan tertekan), $0.5<\mathrm{E} \leq 0.75$ (komunitas dalam keadaan agak seimbang) dan $0.75<\mathrm{E}$ $\leq 1$ (komunitas dalam keadaan seimbang) [40].

\section{Analisis Pola Penyebaran Biota Penempel Mangrove}

Untuk pola penyebaran biota penempel di kawasan reboisasi mangrove Kepulauan Seribu dianalisis menggunakan Indeks Morisita (I $\delta$ ) $[41 ; 42 ; 43 ; 44 ; 45 ; 46]$ dengan kriteria I $\delta=1$ (pola penyebarannya acak), I $\delta$ $<1$ (pola penyebarannya seragam) dan $\mathrm{I} \delta>1$ (pola penyebarannya mengelompok).

\section{HASIL DAN PEMBAHASAN}

\section{Distribusi dan Komposisi Biota Penempel}

Biota penempel di kawasan reboisasi mangrove Kepulauan Seribu ditemukan 3 spesies dari kelas gastropoda (Atilia scripta, Littoraria scabra, Nerita albicilla) dan 1 spesies dari kelas bivalvia (Saccostrea cucullata) (Tabel 1). Menurut [47] keragaman vegetasi mangrove berkorelasi positif terhadap keragaman faunanya, dimana dalam indeks tegakan mangrove yang dewasa terdapat keanekaragaman fauna invertebrata yang lebih tinggi dibandingkan dengan tegakan mangrove yang baru ditanam, kemudian menurut [48], [49] dan [50] komposisi spesies, keanekaragaman, biomassa maupun kelimpahan invertebrata akan berubah apabila ada terjadinya gangguan, eksploitasi ataupun berada di area rehabilitasi mangrove.

Selain itu, Tabel 1 juga memperlihatkan bahwa gastropoda A. scripta hanya ditemukan pada Stasiun 2 dan 3. Hasil ini sama dengan yang ditemukan [51] di ekosistem padang lamun Mara'bombang Kabupaten Pinrang Sulawesi Selatan.
Menurut [52] gastropoda yang ditemukan di habitat mangrove menunjukkan tingkat kesetiaan yang berbeda- beda, dimana beberapa spesiesnya kadang-kadang ditemukan juga di lingkungan lain, kemudian Tabel 1 memperlihatkan bahwa gastropoda $L$. scabra dan bivalvia $S$. cucullata ditemukan merata di semua stasiun dan hasil ini didukung oleh pernyataan [53], dimana gastropoda famili Littoriinidae lebih representatif pada mangrove muda yang baru direhabilitasi. Sementara untuk gastropoda $N$. albicilla pada Tabel 1 memperlihatkan hanya ditemukan pada Stasiun 3. Menurut [54] komposisi gastropoda di vegetasi mangrove yang lebih kedarat, salah satu famili yang mendominasinya adalah Neritidae, kemudian gastropoda famili Neritidae juga lebih melimpah di hutan mangrove dewasa dibandingkan dengan yang baru direboisasi (lebih muda) [53]. Bila dibandingkan dengan [53], [32], [55], [56], [57] maupun [58], hasil kajian biota penempel di kawasan reboisasi mangrove Kepulauan Seribu lebih sedikit jumlah spesiesnya yang ditemukan.

Spesies biota penempel dengan komposisi tertinggi pada kawasan reboisasi mangrove Kepulauan Seribu ditemukan pada gastropoda L. scabra (92.23\%), kemudian diiikuti oleh $S$. cucullata $(02.04 \%)$, A. scripta (01.84\%) dan N. albicilla (02.04\%) (Tabel 2). Rendahnya komposisi gastropoda $N$. albicilla dibandingkan spesies lain didukung oleh pernyataan [59], dimana keragaman famili Neritidae lebih tinggi di perairan tawar ataupun muara, baik itu dalam jumlah genus maupun spesiesnya. Selanjutnya [60] menyatakan bahwa sekitar 100 spesies dari genus Nerita hidup di laut dan batu-batuan intertidal, kemudian [61] menambahkan bahwa spesies dari genus Nerita (famili Neritidae) lebih erat kaitannya dengan lingkungan laut, sedangkan spesies dari Neritina dan Clithon (famili Neritidae) lebih memilih untuk tinggal di habitat air payau atau tawar. 
Tabel 2 Komposisi biota penempel di kawasan reboisasi mangrove Kepulauan Seribu

\begin{tabular}{cllc}
\hline No & \multicolumn{1}{c}{ Jenis Biota Penempel } & \multicolumn{1}{c}{ Famili } & Komposisi (\%) \\
\hline 1 & Atilia scripta $(A S)$ & Buccinidae & 01.84 \\
2 & Littoraria scabra $($ LS $)$ & Littorinidae & 92.23 \\
3 & Nerita albicilla $(N A)$ & Neritidae & 00.20 \\
4 & Saccostrea cucullata $(S C)$ & Ostreidae & 02.04 \\
\hline
\end{tabular}

Tabel 3 Kepadatan biota penempel di kawasan reboisasi mangrove Kepulauan Seribu

\begin{tabular}{|c|c|c|c|}
\hline Stasiun & $\begin{array}{l}\text { Lokasi } \\
\text { (Pulau) }\end{array}$ & $\begin{array}{c}\begin{array}{c}\text { Jenis Biota Penempel } \\
\text { (Filum Moluska) }\end{array} \\
\end{array}$ & $\begin{array}{c}\text { Kepadatan } \\
\left(\text { ind } / \mathbf{m}^{2}\right)\end{array}$ \\
\hline \multirow{3}{*}{1} & \multirow{3}{*}{ Pramuka } & Littoraria scabra & 06.00 \\
\hline & & Saccostrea cucullata & 00.00 \\
\hline & & Rata-Rata & 03.00 \\
\hline \multirow{4}{*}{2} & \multirow{4}{*}{ Panggang } & Littoraria scabra & 10.00 \\
\hline & & Atilia (Columbella) scripta & 01.00 \\
\hline & & Saccostrea cucullata & 00.00 \\
\hline & & Rata-Rata & 04.00 \\
\hline \multirow{5}{*}{3} & \multirow{5}{*}{ Karya } & Littoraria scabra & 14.00 \\
\hline & & Atilia (Columbella) scripta & 01.00 \\
\hline & & Nerita albicilla & 01.00 \\
\hline & & Saccostrea cucullata & 01.00 \\
\hline & & Rata-Rata & 04.00 \\
\hline
\end{tabular}

Tabel 4 Keanekaragaman, dominansi dan keseragaman biota penempel

\begin{tabular}{cccccccc}
\hline \multirow{2}{*}{ Stasiun } & Lokasi & \multicolumn{7}{c}{ Indeks Ekologi } \\
\cline { 3 - 8 } & (Pulau) & H' & Kriteria & C & Kriteria & E & Kriteria \\
\hline 1 & Pramuka & 0.20 & Rendah & 0.94 & Tinggi & 0.05 & Tertekan \\
2 & Panggang & 0.51 & Rendah & 0.84 & Tinggi & 0.13 & Tertekan \\
3 & Karya & 0.13 & Rendah & 0.97 & Tinggi & 0.04 & Tertekan \\
Rata-Rata & $\mathbf{0 . 2 8}$ & Rendah & $\mathbf{0 . 9 2}$ & Tinggi & $\mathbf{0 . 0 7}$ & Tertekan \\
\hline
\end{tabular}

Tabel 5 Pola penyebaran biota penempel di kawasan reboisasi mangrove Kepulauan Seribu

\begin{tabular}{llcl}
\hline \multicolumn{1}{c}{ Jenis Biota Penempel } & Famili & Indeks Morisita (I $\boldsymbol{\delta})$ & \multicolumn{1}{c}{ Kriteria } \\
\hline Atilia (Columbella) scripta & Buccinidae & 0.27 & Seragam (uniform) \\
Littoraria scabra & Littorinidae & 0.00 & Seragam (uniform) \\
Nerita albicilla & Neritidae & 0.00 & Seragam (uniform) \\
Saccostrea cucullata & Ostreidae & 3.00 & Berkelompok (clumped) \\
\hline
\end{tabular}


Tabel 6 Karakteristik lingkungan perairan biota penempel di kawasan reboisasi mangrove Kepulauan Seribu

\begin{tabular}{ccccc}
\hline \multirow{2}{*}{ Stasiun } & \multicolumn{4}{c}{ Kualitas Air } \\
\cline { 2 - 5 } & Suhu $\left({ }^{\circ} \mathbf{C}\right)$ & Salinitas (\%o) & pH & DO* \\
\hline 1 & 32 & 30 & 7.7 & ${ }^{\mathrm{a}} 6.7$ \\
2 & 31 & 33 & 6.6 & ${ }^{\mathrm{b}} 7.0$ \\
3 & 30 & 31 & 7.0 & ${ }^{\mathrm{b}} 6.0$ \\
Baku mutu MNLH (2004) & $\mathbf{2 8 - 3 2}$ & s/d 34 & $\mathbf{7 - 8 . 5}$ & $>\mathbf{5}$ \\
\hline
\end{tabular}

*Data sekunder, ${ }^{\mathrm{a}}$ Faiqoh et al. (2015), ${ }^{\mathrm{b}}$ Riani et al. (2017)

\section{Kepadatan Biota Penempel Mangrove}

Tabel 3 memperlihatkan bahwa kepadatan biota penempel tertingginya berada di Stasiun 2 dan 3 (masing-masing $04.00 \mathrm{ind} / \mathrm{m}^{2}$ ) dengan kepadatan spesies tertingginya adalah L. scabra di Stasiun 3 $\left(14.00 \mathrm{ind} / \mathrm{m}^{2}\right)$. Menurut [62] perubahan komposisi spesies, keanekaragaman, biomassa dan kelimpahan invertebrata dapat mencerminkan status ekosistem mangrove dan dapat digunakan sebagai indikator perubahan, baik itu pada hutan mangrove alami maupun yang baru ditanam. Pernyataan yang sama juga dinyatakan oleh [30], dimana tingkat perekrutan fauna bentik telah dianggap sebagai salah satu kriteria utama dalam menilai keberhasilan program restorasi di suatu kawasan hutan mangrove. Selanjutnya [63], [64], [65] maupun [66] menyatakan bahwa pada umumnya keragaman yang ada di hutan mangrove terdiri dari fauna bentik yang hidup di atau di bawah sedimen, dimana fauna bentik tersebut mempunyai banyak fungsi ekologi dan memainkan peran penting dalam menghubungkan produsen primer dengan karnivora atas atau predator, membantu menguraikan materi organik dan siklus nutrisi melalui aktivitas trofiknya, meningkatkan porositas sedimen serta menciptakan jalur oksigen, nutrisi, air maupun elemen lainnya agar masuk ke dalam sedimen mangrove $[67 ; 68]$.

\section{Keanekaragaman, Dominansi dan Keseragaman Biota Penempel Mangrove}

Tabel 4 memperlihatkan bahwa spesies biota penempel di kawasan reboisasi mangrove Kepulauan Seribu untuk ketiga stasiunnya memiliki keanekaragaman yang rendah, sehingga menyebabkan dominansinya tinggi. Hal ini sesuai dengan hasil penelitian [29] di Qatar, dimana spesies dari filum moluska lebih banyak ditemukan pada habitat alami dibandingkan dengan yang di area penanaman (reboisasi), kemudian [53] menyatakan bahwa sangat sulit untuk melacak komunitas fauna makrobentik pada mangrove yang direhabilitasi, hal ini disebabkan karena ekosistemnya yang belum matang. Selain itu, Tabel 4 juga memperlihatkan bahwa indeks keseragaman biota penempelnya memiliki tekanan di semua stasiun. Hal ini disebabkan oleh tingginya pendominasian yang terjadi. Menurut [69] mangrove merupakan produsen utama yang mempertahankan komunitas fauna makroinvertebrata di daerah intertidal, kemudian karakteristik sedimen mangrove sangat penting bagi makroinvertebrata karena makroinvertebrata menyesesuaikan jenis sedimen dengan makanannya [70]. Selanjutnya [53] menyatakan bahwa vegetasi mangrove dapat memberikan manfaat bagi beberapa gastropoda terhadap mikrohabitatnya dan dapat mengurangi tekanan lingkungan yang ada di sekitarnya.

\section{Pola Penyebaran Biota Penempel Mangrove}

Tabel 5 memperlihatkan bahwa pola penyebaran biota penempel gastropoda ( $A$. scripta, L. scabra, N. albicilla) tergolong seragam $(\mathrm{I} \delta<1)$, sedangkan bivalvia $(S$. cucullata) tergolong mengelompok (I $\delta>1$ ). Menurut [71] distribusi gastropoda di hutan mangrove mempunyai penyebaran yang sempit, dimana dalam penyebarannya, gastropoda dapat menyebar secara menegak ataupun mendatar [72], kemudian [73] menyatakan bahwa bivalvia $S$. cucullata 
hidupnya sering menempel secara bersamasama pada posisi yang sama. Menurut [74] pola sebaran acak dari individu-individu suatu spesies dalam suatu habitat menunjukkan adanya keseragaman (homogenity) dalam lingkungan dan atau tingkah laku yang tidak selektif, dimana pola non-acak (mengelompok dan seragam) secara tidak langsung menyatakan bahwa ada faktor pembatas terhadap keberadaan suatu populasi (pengelompokan menunjukkan bahwa individu-individu berkumpul pada beberapa habitat yang menguntungkan, kejadian ini bisa disebabkan oleh tingkah laku mengelompok, lingkungan yang heterogen, model reproduksi dan sebagainya), sedangkan penyebaran yang seragam dihasilkan dari interaksi negatif antara individu-individu (kompetisi terhadap makanan atau hal-hal khusus lainnya).

\section{Karakteristik Lingkungan}

Hasil pengukuran paramater suhu perairan ketiga stasiun berkisar antara 30 $32^{\circ} \mathrm{C}$, salinitas $30-33 \%$, pH $6.6-7.7$ dan DO $6-7 \mathrm{mg} / \mathrm{l}$ (Tabel 6). Bervariasinya konsentrasi karakteriktik lingkungan di lokasi penelitian, tidak menyebabkan sebagai faktor pembatas bagi kelangsungan hidup mangrove maupun biota penempel di Kepulauan Seribu atau dalam arti lain mangrove Rhizophora spp. dan biota penempel masih bisa mentolerir kualitas air tersebut untuk kelangsungan hidupnya. [75] menyatakan bahwa kualitas air maupun sedimen sangat penting untuk kelangsungan hidup serta kesejahteraan keanekaragaman hayati, terutama di daerah pesisir dan muara sungai yang dikendalikan oleh banyak faktor.

\section{KESIMPULAN}

Biota penempel dari filum moluska di kawasan reboisasi mangrove Kepulauan Seribu ditemukan 4 spesies, dimana 3 spesies dari kelas gastropoda dan 1 spesies dari kelas bivalvia. Gastropoda L. scabra dan bivalvia S. cucullata ditemukan merata di semua stasiun dengan komposisi tertingginya adalah gastropoda L. scabra (92.23\%). Pada Stasiun 2 dan 3 ditemukan kepadatan biota penempel tertinggi (masing-masing $04.00 \mathrm{ind} / \mathrm{m}^{2}$ ) dengan keanekaragaman ketiga stasiunnya tergolong rendah, sehingga menyebabkan dominansinya tinggi dan keseragamannya mengalami tekanan. Selain itu, pola penyebaran biota penempel di kawasan reboisasi mangrove Rhizophora spp. Kepulauan Seribu tergolong seragam dan berkelompok dengan karakteristik lingkungan tidak sebagai faktor pembatas bagi kelangsungan hidup mangrove maupun biota penempelnya.

\section{UCAPAN TERIMAKASIH}

Ucapan terimakasih disampaikan kepada pihak Taman Nasional Kepulauan Seribu (TNKS), Camat Kepulauan Seribu Utara dan Lurah Kelurahan Panggang yang telah memberikan izin sehingga terlaksananya penelitian ini.

\section{DAFTAR PUSTAKA}

[1] Woodroffe, C. D., \& Grindrod, J. "Mangrove biogeography: The role of quaternary environmental and sea-level change". Biogeography, 18(5), 479492. 1991.

[2] Osland, M., Feher, L., Griffith, K., Cavanaugh, K., Enwright, N., Day, R. H., Stagg, C. L., Krauss, K. W., Howard, R. J., Grace, J. B., \& Rogers, K. "Climatic controls on the global distribution, abundance and species richness of mangrove forests". Ecological Monographs, 87(2), 341359. 2016.

[3] Lugo, A. E., \& Snedaker, S. C. "The ecology of mangroves". Annual Review of Ecology and Systematics, 5, 39-64. 1974.

[4] Kuenzer, C., Bluemel, A., Gebhardt, S., Quoc, T. V., \& Dech, S. "Remote sensing of mangrove ecosystems: A review". Remote Sensing, 3(5), 878928. 2011.

[5] Tripathi, R., Shukla, A. K., Shahid, M., Nayak, D., Puree, C., Mohanty, S., Raja, R., Lal, B., Gautam, P., Bhattacharyya, P., Panda, B. B., Kumar, A., Jambhulkar, N. N., \& 
Nayak, A. K. "Soil quality in mangrove ecosystem deteriorates due to rice cultivation". Ecological Engineering, 90, 163-169. 2016.

[6] Agoramoorthy, G., Chen, F., \& Hsu, M. J. "Threat of heavy metal pollution in halophytic and mangrove plants of Tamil Nadu, India". Environmental Pollution, 155(2), 320-326. 2008.

[7] Lewis, M., Pryor, R., \& Wilking, L. "Fate and effects of anthropogenic chemicals in mangrove ecosystems: A review". Environmental Pollution, 159(10), 2328-2346. 2011.

[8] Sandilyan, S., \& Kathiresan, K. "Decline of mangroves - A threat of heavy metal poisoning in Asia". Ocean and Coastal Management, 102, 161168. 2014.

[9] Giri, C., Pengra, B., Zhu, Z., Singh, A., \& Tieszen, L. L. "Monitoring mangrove forest dynamics of the Sundarbans in Bangladesh and India using multi-temporal satellite data from 1973 to 2000". Estuarine, Coastal and Shelf Science, 73(1-2), 91-100. 2007.

[10] Alongi, D. M. "Present state and future of the world's mangrove forests". Environmental Conservation, 29(3), 331-349. 2002.

[11] Valiela, I., Bowen, J. L., \& York, J. K. "Mangrove forests: One of the world's threatened major tropical environments". Bioscience, 51(10), 807-815. 2001.

[12] [FAO] Food and Agriculture Organization. "The World's Mangroves 1980 - 2005: A Thematic Study Prepared in The Frameworkof The Global Forest Resources Assessment 2005". Roma, Itali. 2007.

[13] Feller, I. C., Lovelock, C. E., Berger, U., McKee, K. L., Joye, S. B., \& Ball, M. C. "Biocomplexity in mangrove ecosystems". Annual Review of Marine Science, 2, 395-417. 2010.
[14] Giri, C., Ochieng, E., Tieszen, L. L., Zhu, Z., Singh, A., Loveland, T., Masek, J., \& Duke, N. "Status and distribution of mangrove forests of the world using earth observation satellite data". Global Ecology and Biogeography, 20(1), 154-159. 2011.

[15] Lewis, R. R. "Impacts of dredging in the Tampa Bay Estuary, 1876-1976". Dalam: Proceedings of The Second Annual Conference of the Coastal Society. 1976 November 17 - 20. New Orleans, Louisiana. 1976.

[16] Aboudha, P. A. W., \& Kairo, J. G. "Human-induced stresses on mangrove swamps along the Kenyan coast". Hydrobiologia, 458(1-3), 255-265. 2001.

[17] Hamilton, S. E., \& Casey, D. "Creation of a high spatio-temporal resolution global database of continuous mangrove forest cover for the 21st century (CGMFC-21)". Global Ecology and Biogeography, 25(6), 729 - 738. 2016.

[18] Purnobasuki, H. "Ancaman terhadap hutan mangrove di Indonesia dan langkah strategis pencegahannya". Bulletin PSL Universitas Surabaya, 25, 3-6. 2011.

[19] Field, C. D. "Mangrove rehabilitation: Choice and necessity". Hydrobiologia, 413(0), 47-52. 1999.

[20] Kairo, J. G., Dahdouh-Guebas, F., Bosire, J., \& Koedam, N. "Restoration and management of mangrove systems - A lesson for and from the East African region". South African Journal of Botany, 67(3), 383-389. 2001.

[21] Perry, C. T., \& Berkeley, A. "Intertidal substrate modification as a result of mangrove planting: Impacts of introduced mangrove species on sediment microfacies characteristics". Estuarine, Coastal and Shelf Science, 81(2), 225-237. 2009. 
[22] Rey, J. R., Carlson, D. B., \& Brockmeyer, B. R. "Coastal wetland management in Florida: Environmental concerns and human health". Wetlands Ecology and Management, 20(3), 197211. 2011.

[23] Yao, C. E. "Mangrove reforestation in Central Visayas". Canopy International, 12(2), 6-9. 1986.

[24] Kamali, B., \& Hashim, R. "Mangrove restoration without planting". Ecological Engineering, 37(2), 387391. 2011.

[25] Basyuni, M., \& Sulistiyono, N. "Deforestation and reforestation analysis from land-use changes in North Sumatran Mangroves, 19902015". Dalam: IOP Conference Series: Materials Science and Engineering. 7 8 September 2017. Sumatera Utara, Indonesia. 2018.

[26] Soemodihardjo, S., \& Soerianegara, I. "The status of mangrove forests in Indonesia". Dalam: Proceedings symposium on mangrove management: its ecological and economics considerations. 73 - 114. Bogor: SEAMEO - BIOTROP. 1989.

[27] Kusmana, C. "Management of mangrove ecosystem in Indonesia". Pengelolaan Sumberdaya Alam dan Lingkungan, 1(2), 152-157. 2011.

[28] Pramudji, \& Dharmawan, I. W. E. "Analisis pertumbuhan bibit bakau Rhizophora stylosa Griff. di kawasan rehabilitasi mangrove Tanjung Pasir, Tangerang". Oseanologi dan Limnologi di Indonesia, 1(3), 91-100. 2016.

[29] Bosire, J. O., Dahdouh-Guebas, F., Walton, M., Crona, B. I., Lewis III, R. R., Field, C., Kairo, J. G., \& Koedam, N. "Functionality of restored mangroves: A review". Aquatic Botany, 89(2), 251-259. 2008.
[30] Field, C. D. "Rehabilitation of mangrove ecosystems: An overview". Marine Pollution Bulletin, 37, 383-392. 1998.

[31] Teal, J. M., \& Weishar, L. "Ecological engineering, adaptive management, and restoration management in Delaware Bay salt marsh restoration". Ecological Engineering, 25, 304-314. 2005.

[32] Chen, G. C., \& Ye, Y. "Restoration of Aegiceras corniculatum mangroves in Jiulongjiang Estuary changed macrobenthic faunal community". Ecological Engineering, 37(2), 224-228. 2011.

[33] Dale, P. E. R., Knight, J. M., \& Dwyer, P. G. "Mangrove rehabilitation: A review focusing on ecological and institutional issues". Wetlands Ecology and Management, 22(6), 587 - 604. 2014.

[34] Dharma, B. "Siput dan Kerang Indonesia (Indonesian Shells)". Jakarta, Indonesia. 1988.

[35] Ernanto, R., Agustriani, F., \& Aryawati, R. "Struktur komunitas gastropoda pada ekosistem mangrove di muara Sungai Batang Ogan Komering Ilir Sumatera Selatan". Maspari, 1, 73-78. 2010.

[36] Odum, E. P. "Fundamentals of Ecology 3rd Edition". W. B. Saunders Co. Philadelphia. 1971.

[37] Southwood, T. R. E. "Ecological Methods". London, Inggris. 1978.

[38] Brower, J. E., \& Zar, J. H. "Field and Laboratory Methods for General Ecology Second Edition". Dubuque, IA : W.C. Brown Publishers. 1984.

[39] Krebs, C. J. "Ecological Methodology". New York: University of British Columbia, Harper Collins Publishers. 1989.

[40] Setyobudiandi, I., Sulistiono, Yulianda, F., Kusmana, C., Hariyadi, S., Damar, 
A., Sembiring, A., \& Bahtiar. "Sampling dan Analisis Data Perikanan dan Kelautan: Terapan Metode Pengambilan Contoh di Wilayah Pesisir dan Laut". Fakultas Perikanan dan Ilmu Kelautan, Institur Pertanian Bogor. Bogor, Indonesia. 2009.

[41] Morisita, M. "Measuring of dispersion of individuals and analysis of the distributional patterns". Memories of the Faculty of Science Kyushu University Series E (Biology), 2(4), 215-235. 1959.

[42] Krebs, C. J. "Ecology: The Experimental Analysis of Distribution and Abundance". New York: Harper \& Row. 1972.

[43] Poole, R. W. "An Introduction to Quantitative Ecology". New York: McGraw-Hill. 1974.

[44] Kusmana, C., \& Istomo. "Ekologi Hutan. Laboratorium Kehutanan Fakultas Kehutanan". Institut Pertanian Bogor. Bogor. 1995.

[45] Sakai, S., Momose, K., Yumoto, T., Nagamitsu, T., Nagamasu, H., Hamid, A. A., \& Nakashizuka, T. "Plant reproductive phenology over four years including an episode of general flowering in a lowland dipterocarp forest, Sarawak, Malaysia". American Journal of Botany, 86(10), 1414-1436. 1999.

[46] Jongjitvimol, T., Boontawon, K., Wattanachaiyingcharoen, W., \& Deowanish, S. "Nest dispersion of a stingless bee species, Trigona collina Smith, 1857 (Apidae, Meliponinae) in a mixed deciduous forest in Thailand". The Natural History Journal of Chulalongkorn University, 5(2), 69-71. 2005.

[47] Macintosh, D. J., Ashtona, E. C., \& Havanon, S. "Mangrove rehabilitation and intertidal biodiversity: A study in the Ranong Mangrove Ecosystem,
Thailand". Estuarine, Coastal and Shelf Science, 55(3), 331-345. 2002.

[48] Skilleter, G. A. "Validation of rapid assessment of damage in urban mangrove forests and relationships with molluscan assemblages". The Marine Biological Association of the United Kingdom, 76(3), 701-716. 1996.

[49] Skilleter, G. A., \& Warren, S. "Effects of habitat modification in mangroves on the structure of mollusc and crab assemblages". Experimental Marine Biology and Ecology, 244, 107-129. 2000.

[50] Bosire, J. O., Dahdouh-Guebas, F., Kairo, J. G., Cannicci, S., \& Koedam, N. "Spatial variations in macrobenthic fauna recolonisation in a tropical mangrove bay". Biodiversity and Conservation, 13, 1059-1074. 2004.

[51] Hasniar, Litaay, M., \& Priosambodo, D. "Biodiversitas gastropoda di padang lamun perairan Mara'bombang Kabupaten Pinrang Sulawesi Selatan". Torani, 23(3), 127-136. 2013.

[52] Reid, D. G., Dyal, P., Lozouet, P., Glaubrecht, M., \& Williams, S. T. "Mudwhelks and mangroves: The evolutionary history of an ecological association (Gastropoda: Potamididae)". Molecular Phylogenetics and Evolution, 47, 680699. 2008.

[53] Chen, G., Ye, Y., \& Lu, C. "Changes of macro-benthic faunal community with stand age of rehabilitated Kandelia candel mangrove in Jiulongjiang Estuary, China". Ecological Engineering, 31(3), 215-224. 2007.

[54] Macnae, W. "A general account of the fauna and flora of mangrove swamps and forests in the Indo-West-Pacific region". Advances in Marine Biology, 6, 73-270. 1968.

[55] Irma D, \& Sofyatuddin, K. "Diversity of gastropods and bivalves in mangrove 
ecosystem rehabilitation areas in Aceh Besar and Banda Aceh districts, Indonesia". Aquaculture, Aquarium, Conservation \& Legislation International Journal of The Bioflux Society, 5(2), 55-59. 2012.

[56] Omar, A., Bin, S., Sirante, R., Suwarni, \& Litaay, M. "Keanekaragaman gastropoda (moluska) di ekosistem mangrove Kabupaten Sinjai, Sulawesi Selatan". Dalam Seminar Nasional Moluska III. 14 Juni 2012. Makassar, Indonesia. 2012.

[57] Samsi, A. N., Omar, S. B. N., \& Niartiningsih, A. "Pengaruh faktor lingkungan terhadap pola penyebaran moluska pada ekosistem mangrove alami dan hasil rehabilitasi". Fish Scientiae, 8(1), 51-60. 2018.

[58] Al-Khayat, J. A., Abdulla, M. A., \& Alatalo, J. M. "Diversity of benthic macrofauna and physical parameters of sediments in natural mangroves and in afforested mangroves three decades after compensatory planting". Aquatic Sciences, 81(4), 1-11. 2019.

[59] Kano, Y., Chiba, S., \& Kase, T. "Major adaptive radiation in neritopsine gastropods estimated from $28 \mathrm{~S}$ rRNA sequences and fossil records". Proceedings of The Royal Society B: Biological Sciences, 269(1508), 24572465. 2002.

[60] Quintero-Galvis, J., \& Castro, L. R. "Molecular phylogeny of the Neritidae (Gastropoda: Neritimorpha) based on the mitochondrial genes Cytochrome Oxidase I (COI) and 16S Rrna". Acta Biologica Colombiana, 18(2), 307-318. 2013.

[61] Tan, S. K., \& Clements, R. "Taxonomy and distribution of the Neritidae (Mollusca: Gastropoda) in Singapore". Zoological Studies, 47(4), 481-494. 2008.

[62] Zvonareva, S., Kantor, Y., Li, X., \& Britayev, T. "Long-term monitoring of
Gastropoda (Mollusca) fauna in planted mangroves in central Vietnam". Zoological Studies, 54(39), 1-16. 2015.

[63] Saravanakumar, A., Serebiah, J. S., Thivakaran, G. A., \& Rajkumar, M. "Benthic macrofaunal assemblage in the arid zone mangroves of Gulf of Kachchh - Gujarat". Ocean University of China (Oceanic and Coastal Sea Research), 6(3), 303-309. 2007.

[64] George, A. D. I., Abowei, J. F. N., \& Alfred-Ockiya, J. F. "The distribution, abundance and seasonality of benthic macro invertebrate in Okpoka Creek sediments, Niger Delta, Nigeria". Applied Sciences Engineering and Technology, 2(1), 11-18. 2010.

[65] Xiping, Z., Lizhe, C., \& Sujing, F. "Comparison of meiofaunal abundance in two mangrove wetlands in Tong'an Bay, Xiamen, China". Ocean University of China (Oceanic and Coastal Sea Research), 14(5), 816-822. 2015.

[66] Xinwei, C., Lizhe, C., Xiping, Z., \& Yiyong, R. "Geographical variation in oligochaete density and biomass in subtropical mangrove wetlands of China". Ocean University of China (Oceanic and Coastal Sea Research), 16(5), 925-931. 2017.

[67] Kon, K., Kurokura, H., \& Tongnunui, P. "Influence of a microhabitat on the structuring of the benthic macrofaunal community in a mangrove forest". Hydrobiologia, 671, 205-216. 2011.

[68] Pravinkumar, M., Murugesan, P., Prakash, R. K., Elumalai, V., Viswanathan, C., \& Raffi, S. M. "Benthic biodiversity in the Pichavaram mangroves, Southeast Coast of India". Oceanography and Marine Science, 4(1), 1-11. 2013.

[69] Camilleri, J. C. "Leaf-litter processing by invertebrates in a mangrove forest in Queensland". Marine Biology, 114(1), 139-145. 1992. 
[70] Alfaro, A. C. "Benthic macroinvertebrate community composition within a mangrove/seagrass estuary in Northern New Zealand". Estuarine, Coastal and Shelf Science, 66, 97-110. 2006.

[71] Tuheteru, M., Notosoedarmo, S., \& Martosupono, M. "Distribusi gastropoda di ekosistem mangrove". Dalam: Prosiding Seminar Nasional Raja Ampat - Waisai. 12 - 13 Agustus 2014. Papua Barat, Indonesia. A-151 A-156. 2014.

[72] Mujiono, N. "Mudwhelks (Gastropoda: Potamididae) from mangroves of Ujung Kulon National Park, Banten". Biologi, 13(2), 51-56. 2009.

[73] Tapilatu, Y., \& Pelasula, D. "Biota penempel yang berasosiasi dengan mangrove di Teluk Ambon Bagian Dalam". Ilmu dan Teknologi Kelautan Tropis, 4(2), 267-279. 2012.

[74] Pemberton, S. G., \& Frey, R. W. "Quantitative methods in ichnology: Spatial distribution among population". Lethaia, 17, 33-49. 1984.

[75] Nobi, E. P., Dilipan, E., Thangaradjou, T., Sivakumar, K., \& Kannan, L. "Geochemical and geo-statistical assessment of heavy metal concentration in the sediments of different coastal ecosystems of Andaman Islands, India". Estuarine, Coastal and Shelf Science, 87(2), 253264. 2010. 